\title{
ODREĐIVANJE DINAMIČKOG KOEFICIJENTA NA MOSTOVIMA
}

\author{
Ivana Štimac Grandić \\ Građevinski fakultet u Rijeci, doc.dr.sc. \\ Davor Grandić \\ Građevinski fakultet u Rijeci, doc.dr.sc. \\ Renata Mužić \\ Građevinski fakultet u Rijeci, mag.ing.aedif.
}

\begin{abstract}
Sažetak: U radu je, sa svrhom određivanja globalnog dinamičkog koeficijenta mosta, korišten programski paket DARK kojim se može provesti dinamički proračun ravninskih štapnih konstrukcija pod djelovanjem pokretnog opterećenja. Programom DARK mogu se, uz osnovne dinamičke karakteristike, izračunati dinamički progibi, brzine i ubrzanja konstrukcije izložene djelovanju opterećenja koje se kreće konstrukcijom. Primjena programa za određivanje globalnog dinamičkog koeficijenta prikazana je na modelu mosta Drave u Osijeku. Uporabom navedenog programa određeni su dinamički progibi mosta zbog prometovanja različitih kamiona različitim brzinama po mostu i uspoređeni sa statičkim progibima od istih opterećenja, tj. određeni su dinamički koeficijenti. Ovako određeni dinamički koeficijenti uspoređeni su s normama i pravilnicima predviđenim koeficijentima.
\end{abstract}

Ključne riječi: dinamički proračun, dinamički koeficijent, most, pokretno opterećenje

\section{DETERMINATION OF BRIDGE GLOBAL DYNAMIC FACTOR}

Abstract: In this paper, in order to determine the global dynamic factor of the bridge, a software DARK is used. Beside the basis dynamic characteristic the Software DARK can calculate the dynamic deflections, velocities and accelerations of $2 \mathrm{D}$ beam-like structures exposed to moveable forces. The application of the software to determine the global dynamic factor is shown on the model of the bridge Drava in Osijek. By using the DARK, the dynamic deflections due to moving different trucks with different speeds over the bridge have been determined. The dynamic factors were determined by comparing the dynamic deflections with the static ones. Calculated dynamic factors are compared with the dynamic factors anticipated in different codes and standards.

Key words: dynamic analysis, dynamic factor, bridge, moveable load 


\section{Uvod}

Zgrade i inženjerske konstrukcije su osim statičkim djelovanjima, često izložene i dinamičkim djelovanjima koja u vremenu mogu mijenjati smjer i intenzitet, ali i položaj na konstrukciji. Najčešća dinamička djelovanja su opterećenje vjetrom, inercijskim potresnim silama, te ona prouzročena radom strojeva, prometom ili izvanrednim djelovanjima (udar, eksplozija) na građevinu. Mostovi u uporabi mogu biti izloženi dinamičkim djelovanjima prometa, vjetra, potresa i ostalim izvanrednim djelovanjima. Dominantno vertikalno dinamičko djelovanje koje djeluje na rasponsku konstrukciju mosta je prometno djelovanje. Premda ovo djelovanje ima dinamički karakter, kod proračuna konstrukcije zamjenjuje se statičkim opterećenjem. U prošlosti su razne norme, kako hrvatske [1, 2] tako i drugih europskih zemalja [3], propisivale vrijednosti dinamičkog koeficijenta kojim se množilo statičko prometno opterećenje na rasponskoj konstrukciji mosta. Prema tim normama, dinamički koeficijent je ovisio o rasponu, brzini kretanja vozila, omjeru stalnog i pokretnog opterećenja itd. U važećim normama za određivanje opterećenja cestovnih mostova [4] dinamički faktor nije posebno definiran, već je ugrađen u normirano statičko opterećenje.

U radu je, na primjeru cestovnog mosta preko rijeke Drave u Osijeku koji je projektiran prema Pravilniku [2] u kojem je bilo potrebno odrediti dinamički koeficijent, prikazano kako je numeričkim proračunom, uporabom programa DARK [6] kojim se može provesti dinamički proračun ravninskih štapnih konstrukcija pod djelovanjem pokretnog opterećenja, moguće odrediti globalne dinamičke koeficijente rasponske konstrukcije mosta. Ovako određeni dinamički koeficijenti uspoređeni su s normama i pravilnicima predviđenim koeficijentima [1-3].

\section{Opis mosta}

Cestovni most preko rijeke Drave u Osijeku srušen je tijekom Domovinskog rata. Srušena konstrukcija je potpuno uklonjena i na starim kesonskim temeljima u rijeci sagrađeni su novi stupovi. Preko obnovljenog donjeg ustroja izvedena je nova, vrlo vitka čelična sandučasta konstrukcija mosta. Sam čelični sanduk ima širinu $5,70 \mathrm{~m}$ i visinu 2,40 m, a ukupna širina mosta je 13,20 m.

Projektirani statički sustav konstrukcije je kontinuirani nosač preko tri raspona, duljine $66,28+68,00+$ 66,28 . Most je namijenjen cestovnom i pješačkom prometu, ima dva kolnička traka širine $3,75 \mathrm{~m}$ i obostrano pješačke hodnike širine $2,55 \mathrm{~m}$. Poprečni presjeci u sredini raspona i nad ležajem prikazani su na slikama 1 i 2, a uzdužna dispozicija mosta prikazana je na slici 3.

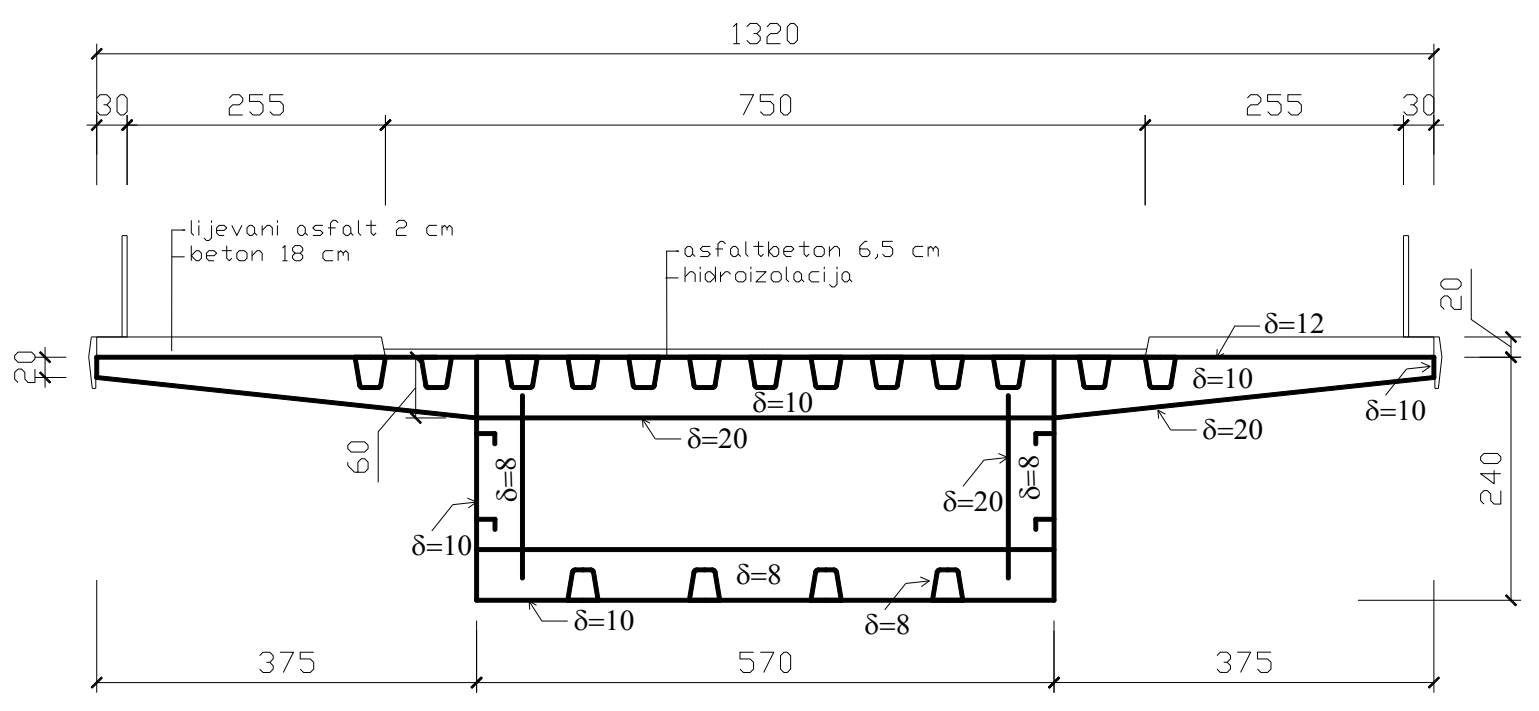

Slika 1 - Poprečni presjek mosta u sredini raspona 


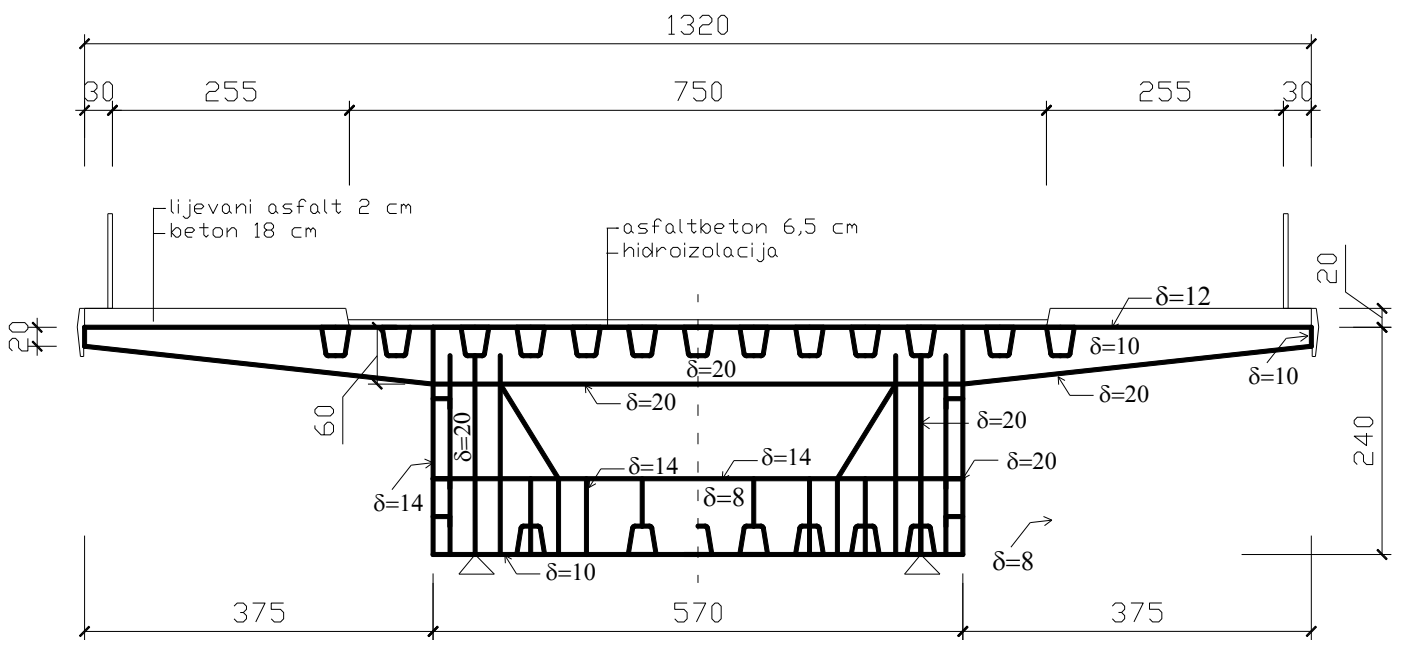

Slika 2 - Poprečni presjek mosta nad ležajem
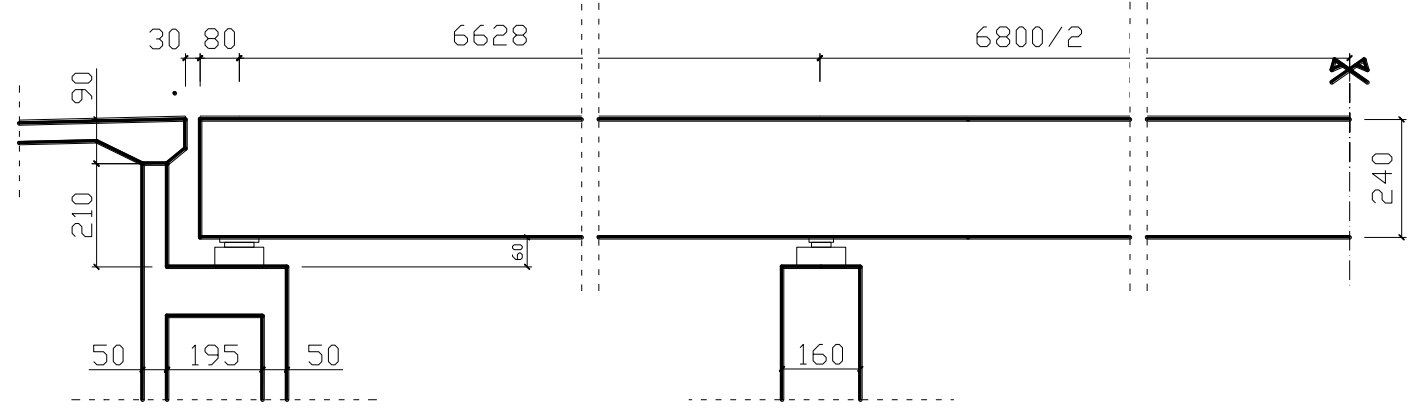

Slika 3 - Uzdužna dispozicija mosta (lijeva plovica)

\section{Pokusno opterećenje mosta}

Most je podvrgnut pokusnom opterećenju prije puštanja u promet. Provedena su statička i dinamička ispitivanja. Opterećivanje mosta je provedeno s osam teških kamiona [5] čije su sheme i osovinske težine prikazane na slikama 4 i 5 i u tablici 1 . Kod dinamičkih ispitivanja mjerene su vlastite frekvencije i periodi vibracija, te dinamički koeficijenti uzrokovani prolaskom teških kamion brzinama od 20 km/h, 40 km/h i 60 km/h.
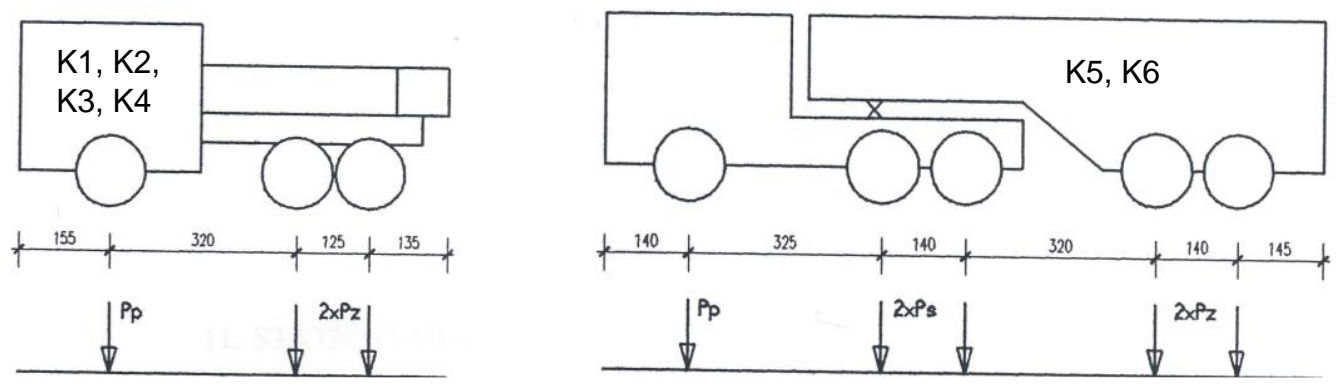

Slika 4 - Sheme i oznake kamiona K1-K6 [5] 

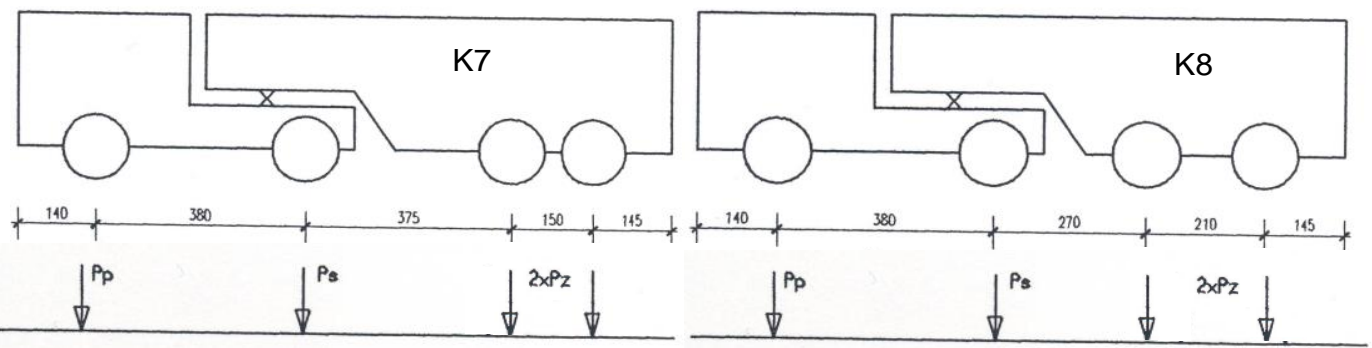

Slika 5 - Sheme i oznake kamiona K7 i K8 [5]

\section{Tablica 1 - Osovinske težine vozila}

\begin{tabular}{|c|c|c|c|}
\hline KAMION & $\begin{array}{c}\text { Težina prednje osovine } \\
\mathrm{Pp}[\mathrm{kN}]\end{array}$ & $\begin{array}{c}\text { Težina srednje osovine } \\
\mathrm{Ps}[\mathrm{kN}]\end{array}$ & $\begin{array}{c}\text { Težina zadnje osovine } \\
\mathrm{Pz}[\mathrm{kN}]\end{array}$ \\
\hline K1 & 72,00 & - & $2 \times 102,60$ \\
\hline K2 & 69,80 & - & $2 \times 103,00$ \\
\hline K3 & 77,80 & - & $2 \times 102,60$ \\
\hline K4 & 73,60 & - & $2 \times 103,50$ \\
\hline K5 & 64,40 & $2 \times 83,90$ & $2 \times 102,40$ \\
\hline K6 & 66,60 & $2 \times 90,40$ & $2 \times 109,90$ \\
\hline K7 & 72,20 & 127,20 & $2 \times 107,10$ \\
\hline K8 & 73,40 & 142,00 & $2 \times 104,30$ \\
\hline
\end{tabular}

Izmjereni period slobodnih vibracija (srednja vrijednost 18 mjerenja) je 0,556 sekundi, tj. izmjerena frekvencija iznosi $1,8 \mathrm{~Hz}$. Tijekom pokusnog ispitivanja mjereni su i dinamički koeficijenti, no njihove vrijednosti nisu reprezentativne za ovaj rad jer je dinamički koeficijent određen iz mjerenja dinamičkog progiba u sredini prvog raspona na konzolnom dijelu konstrukcije, gdje se osim vibriranja glavne raponske konstrukcije (sanduka) mogu pobuditi i vibracije konzole (lokalni učinci) pa tako određen koeficijent ne možemo smatrati globalnim dinamičkim koeficijentom.

\section{Proračun mosta}

\subsection{Opis programa DARK}

Program DARK $[6,7]$ osmišljen je i izrađen na Građevinskom fakultetu U Rijeci (autor prof. I. Kožar). Nastao je kao nadogradnja programa za proračun ravninskih štapnih konstrukcija OKVIR u sklopu magistarskog rada [8] i uz pomoć autora programa. Program DARK omogućuje, osim statičkog proračuna, dinamički proračun različitih vrsta ravninskih štapnih konstrukcija koji obuhvaća određivanje osnovnih oblika vibriranja, vlastitih vektora, perioda i frekvencija vibriranja i proračun dinamičkih progiba, brzina i ubrzanja bilo kojeg čvora numeričkog modela nastalog zbog opterećenja modela pokretnim silama [9]. Program omogućava dinamički proračun konstrukcije zbog djelovanja nekoliko pokretnih sila istovremeno. Omogućeno je zadavanje do 5 sila na proizvoljnom međusobnom razmaku. Intenziteti sila mogu biti nepromjenjivi (konstantni) ili promjenjivi u vremenu. Sile se mogu kretati proizvoljnom jednolikom brzinom preko odabranih čvorova konstrukcije. To omogućuje dinamički proračun, primjerice, rešetke kod koje pokretni teret prelazi samo preko donjeg ili gornjeg pojasa konstrukcije. Algoritam proračuna dinamičkog odgovora konstrukcije (pomaka, brzina i ubrzanja) zbog pokretnog 
se opterećenja bazira na metodi direktne linearne ekstrapolacije s prosječnim ubrzanjem, na način da se za svaki vremenski korak, rješavanjem pseudostatičkog problema, određuju inkrementalni pomaci, brzine i ubrzanja pojedinog čvora numeričkog modela. Prednost algoritma baziranog na metodi direktne linearne ekstrapolacije $s$ prosječnim ubrzanjem u odnosu na neke druge metode (primjerice iteracije implicitnim metodama, metode $s$ linearnim ubrzanjem) je u tome da je metoda bezuvjetno stabilna, tj, nema kritičnog vremenskog koraka. Autori, prema vlastitim iskustvima u korištenju programa, preporučuju da diskretizacija u prostoru bude relativno gusta da bi se izbjegao problem do kojega može doći u rješavanju dinamičke jednadžbe gibanja, gdje matricom diskretnih masa opisujemo masu kontinuirano raspoređenu duž konstrukcije (primjerice kod kontinuiranih štapnih sustava 20 ili više elemenata po rasponu).

U programu je potrebno, osim zadavanja intenziteta sila, njihovog međusobnog razmaka, brzine kretanja sila, zadati i trajanje vremenskog koraka te ukupni broj vremenskih koraka za koje će se provesti dinamički proračun. Također je potrebno zadati konstrukcijsko prigušenje. Nakon provedene dinamičke analize, program omogućava numerički i grafički prikaz osnovnih oblika vibriranja, numerički prikaz vlastitih frekvencija, perioda vibriranja i vlastitih vektora, te numerički i grafički prikaz progiba, brzine ili ubrzanja bilo kojeg čvora modela u vremenu.

\subsection{Proračunski model mosta}

Za proračun je izrađen model u kojemu je konstrukcija mosta podijeljena u mrežu konačnih elemenata: 76 čvorova, 75 štapova (slika 6). Za potrebe provedbe dinamičke analize, svakom čvoru pridružena je masa dobivena zbrajanjem masa polovica štapova koje su ravnomjerno raspoređene u čvorove.

Štapovi 1-7 i $69-75$ su duljine 2,53 m, štapovi 8-11 i $65-68$ su duljine $3,08 \mathrm{~m}$, štapovi 12 i 64 su duljine 3,11 m, štapovi 13, 14, 62, 63 su 2 m dugi, štapovi $15-19$ i $67-61$ su 3,23 dugi, štapovi 20 i 56 su 3,28 m dugi, štapovi 21-24 i 52-55 su 1,94 m dugi, štapovi 25 i 51 su 1,95 m dugi, štapovi 26 i 50 su 2,42 m dugi, štapovi 27-33 i 4349 su 2,43 m dugi, štapovi 34-37 i 39-42 su 3,23 m dugi, a štap 42 je duljine 3,3 m.

Tablica 2 - Ploštine, momenti inercije i težine presjeka konačnih elemenata (štapova)

\begin{tabular}{|c|c|c|c|}
\hline Presjek & $\begin{array}{c}\text { Ploština presjeka } A \\
{\left[\mathrm{~m}^{2}\right]}\end{array}$ & $\begin{array}{c}\text { Moment inercije } I \\
{\left[\mathrm{~m}^{4}\right]}\end{array}$ & $\begin{array}{c}\text { Težina } g \\
{\left[\mathrm{kN} / \mathrm{m}^{3}\right]}\end{array}$ \\
\hline 1 & 0,3300 & 0,3338 & 143,25 \\
\hline 2 & 0,3610 & 0,3858 & 133,79 \\
\hline 3 & 0,3300 & 0,3338 & 140,27 \\
\hline 4 & 0,4280 & 0,4727 & 123,11 \\
\hline 5 & 0,353 & 0,3647 & 135,06 \\
\hline
\end{tabular}

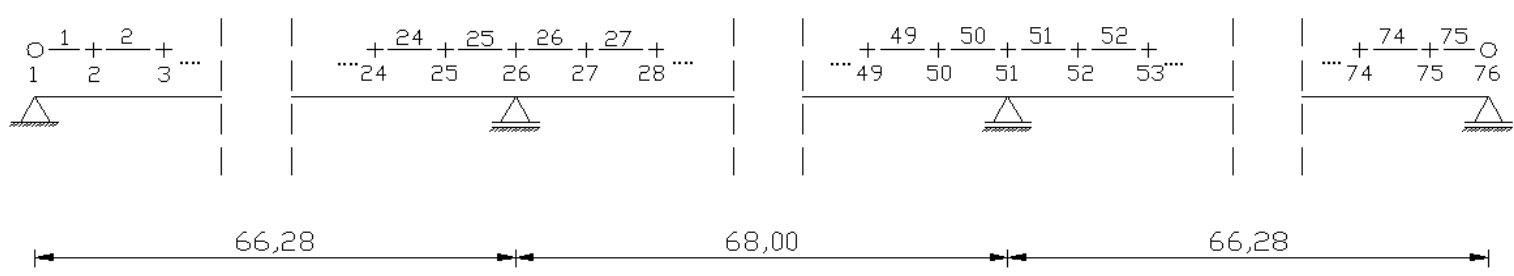

\section{Slika 6 - Raspored čvorova i štapova}

Proračunski model je sastavljen od pet različitih presjeka (ovisno o karakteristikama poprečnog presjeka mosta) koji su pridruženi pojedinom konačnom elementu (štapu). Presjek 1 je pridružen štapovima 1-7 i 69-75, presjek 2 štapovima 8-14 i 63-58, presjek 3 štapovima 15-20, 34-42 i 56-61, presjek 4 štapovima 21-29 i 47-55 a presjek 5 štapovima $30-33$ i 43-46. Modul elastičnosti isti je za sve presjeke i iznosi $E=2,110^{8} \mathrm{kN} / \mathrm{m}^{2}[5]$. Ploštine, momenti inercije i težine pojedinih presjeka štapnih elemenata prikazane su u tablici 2 [5]. Težine po 
dužnom metru određene su uzimajući u obzir vlastitu težinu nosive čelične konstrukcije i vlastitu težinu gornjih slojeva (asfalt, hidroizolacija, pješačka staza, rubnjak, ograda i vijenac).

\subsection{Dinamički proračun konstrukcije}

Izračunani periodi vibracija i vlastite frekvencije su sljedeći: $T_{1}=0,714 \mathrm{~s}, \mathrm{f}_{1}=1,4 \mathrm{~Hz}, \mathrm{~T}_{2}=0,54 \mathrm{~s}, \mathrm{f}_{2}=$ je $1,85 \mathrm{~Hz}$. $\mathrm{T}_{3}=0,364 \mathrm{~s}, \mathrm{f}_{3}=2,75 \mathrm{~Hz}$. Izmjerena vrijednost frekvencije slobodnih vibracija od $1,8 \mathrm{~Hz}$ blizu je vrijednosti frekvencije drugog vlastitog oblika vibriranja od $1,85 \mathrm{~Hz}$ (razlika izračunane i izmjerene vrijednosti je 2,77\%), iz čega se može zaključiti da je tijekom ispitivanja pobuđen drugi vlastiti oblik vibriranja. Za proračun dinamičkog progiba korištena su opterećenja koja simuliraju kamione korištene pri pokusnom opterećenju mosta. Za razmak sila koje se kreću modelom konstrukcije intenzitet je određen prema tablici 1 i slikama 4 i 5 za svaki kamion. Brzine sila su $20 \mathrm{~km} / \mathrm{h}, 40 \mathrm{~km} / \mathrm{h} \mathrm{i} 60 \mathrm{~km} / \mathrm{h}$.

Za brzinu od $20 \mathrm{~km} / \mathrm{h}$, vrijeme prelaska vozila preko mosta podijeljeno je na 1000 vremenskih koraka po $0,04 \mathrm{~s}$ po koraka. Za brzinu od $40 \mathrm{~km} / \mathrm{h}$ vrijeme prelaska vozila preko mosta podijeljeno je na 500 vremenskih koraka po $0,04 \mathrm{~s}$ po koraku. Za brzinu kamiona od $60 \mathrm{~km} / \mathrm{h}$ vrijeme prelaska vozila preko mosta podijeljeno je na 500 vremenskih koraka po 0,04 s po koraku. Konstrukcijsko prigušenje je $3 \%$.

Na slikama 7-14 dani su grafički prikazi dinamičkog progiba čvora 13 koji se nalazi u sredini prvog raspona za različite brzine prijelaza kamiona preko rasponske konstrukcije mosta.

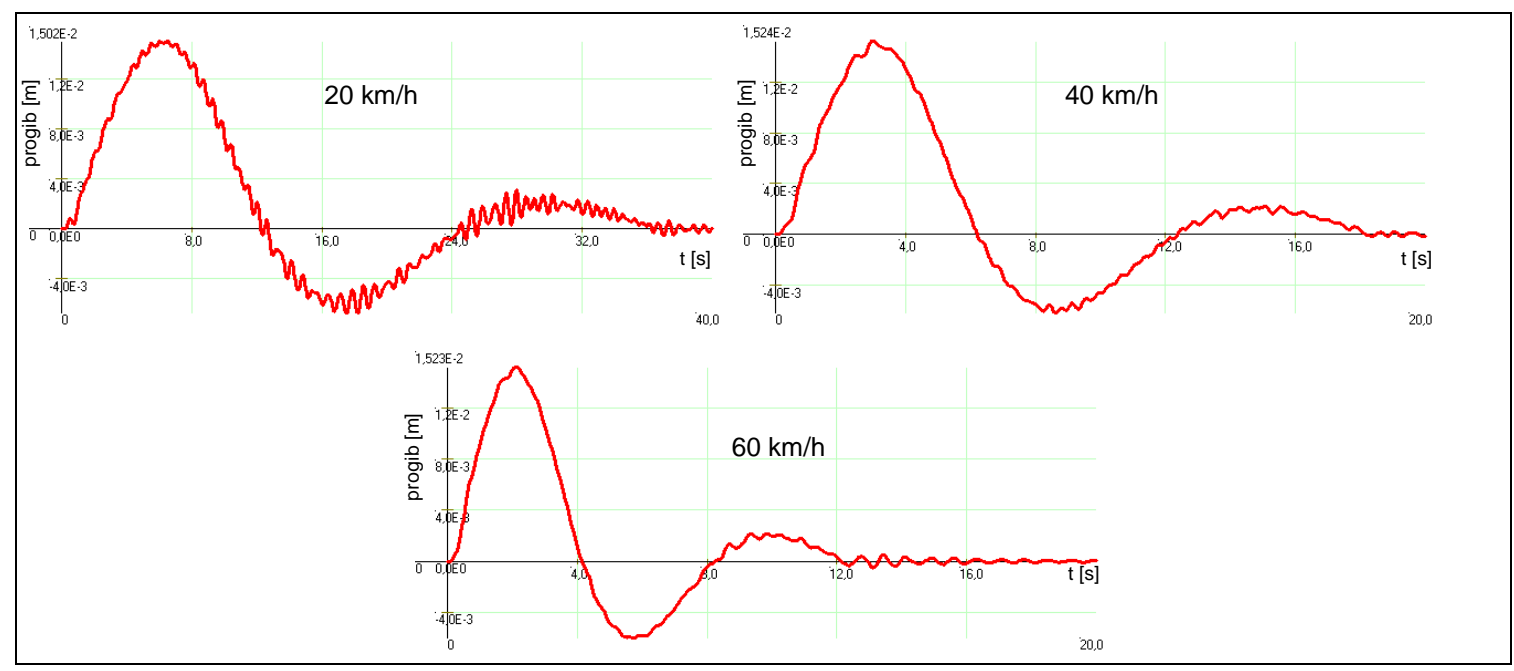

Slika 7 - Grafički prikazi progiba čvora 13 od prelaska kamiona K1

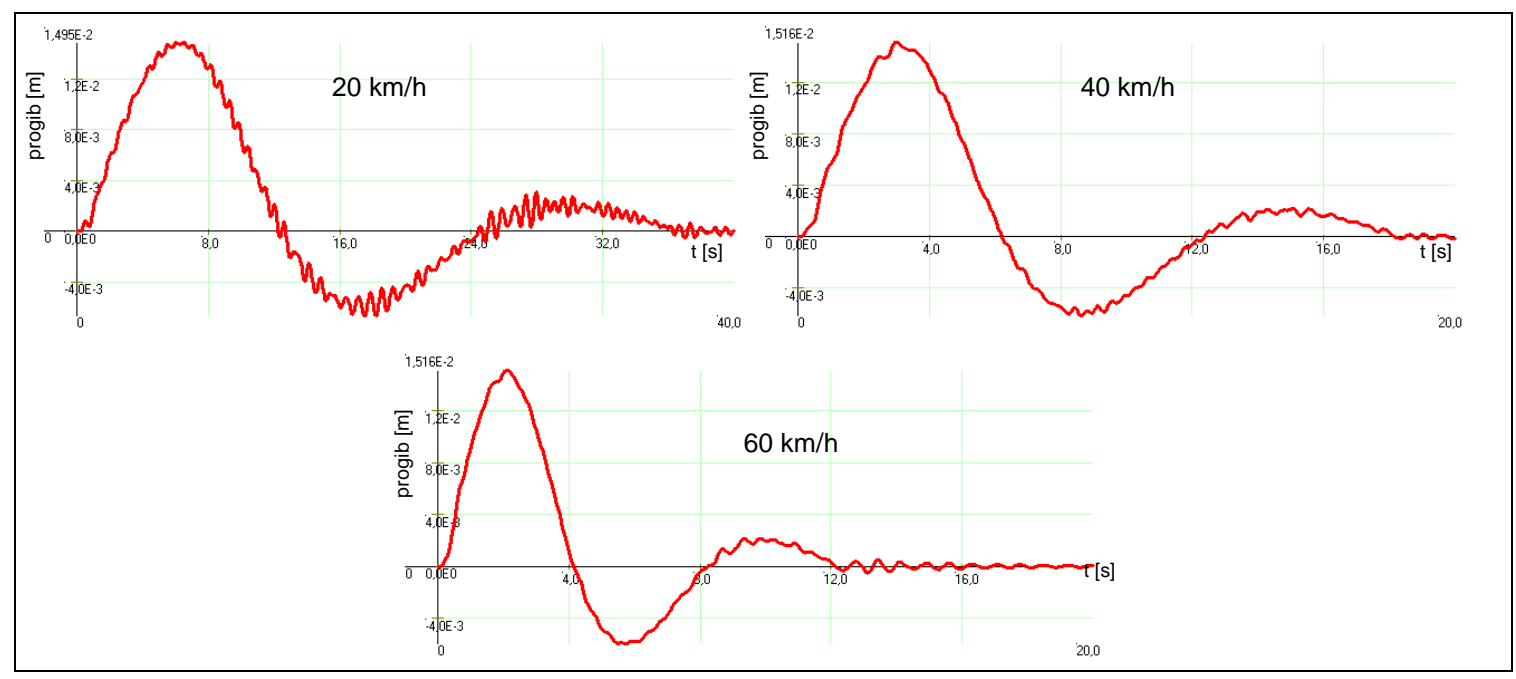


Slika 8 - Grafički prikazi progiba čvora 13 od prelaska kamiona K2

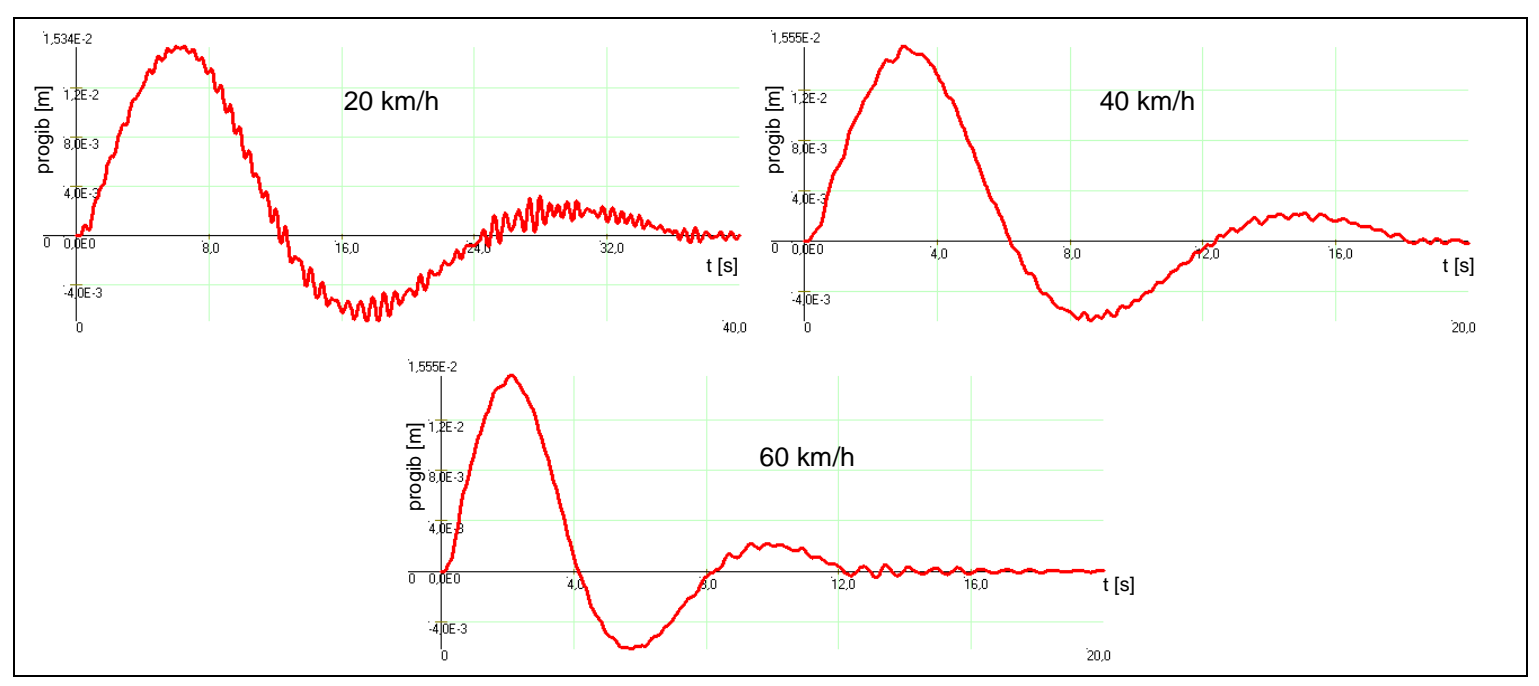

Slika 9 - Grafički prikazi progiba čvora 13 od prelaska kamiona K3

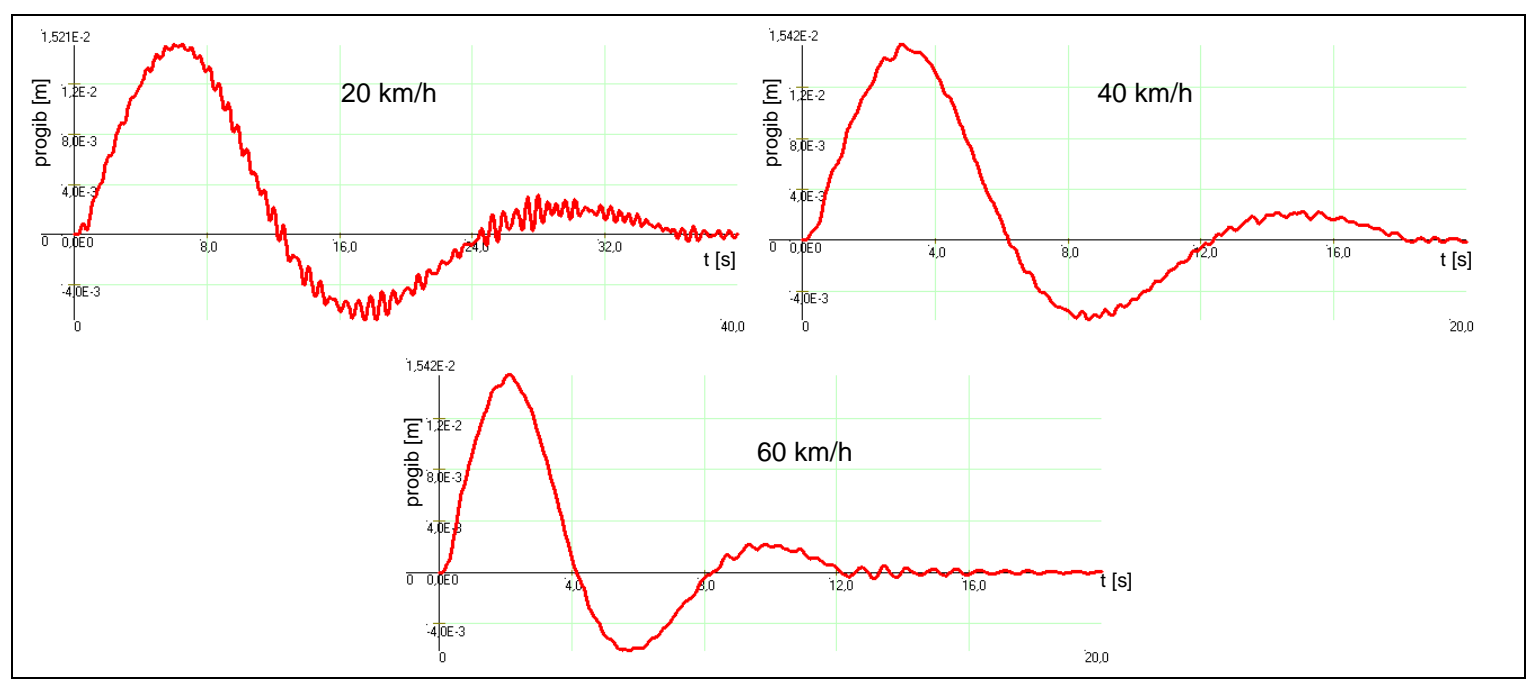

Slika 10 - Grafički prikazi progiba čvora 13 od prelaska kamiona K4 

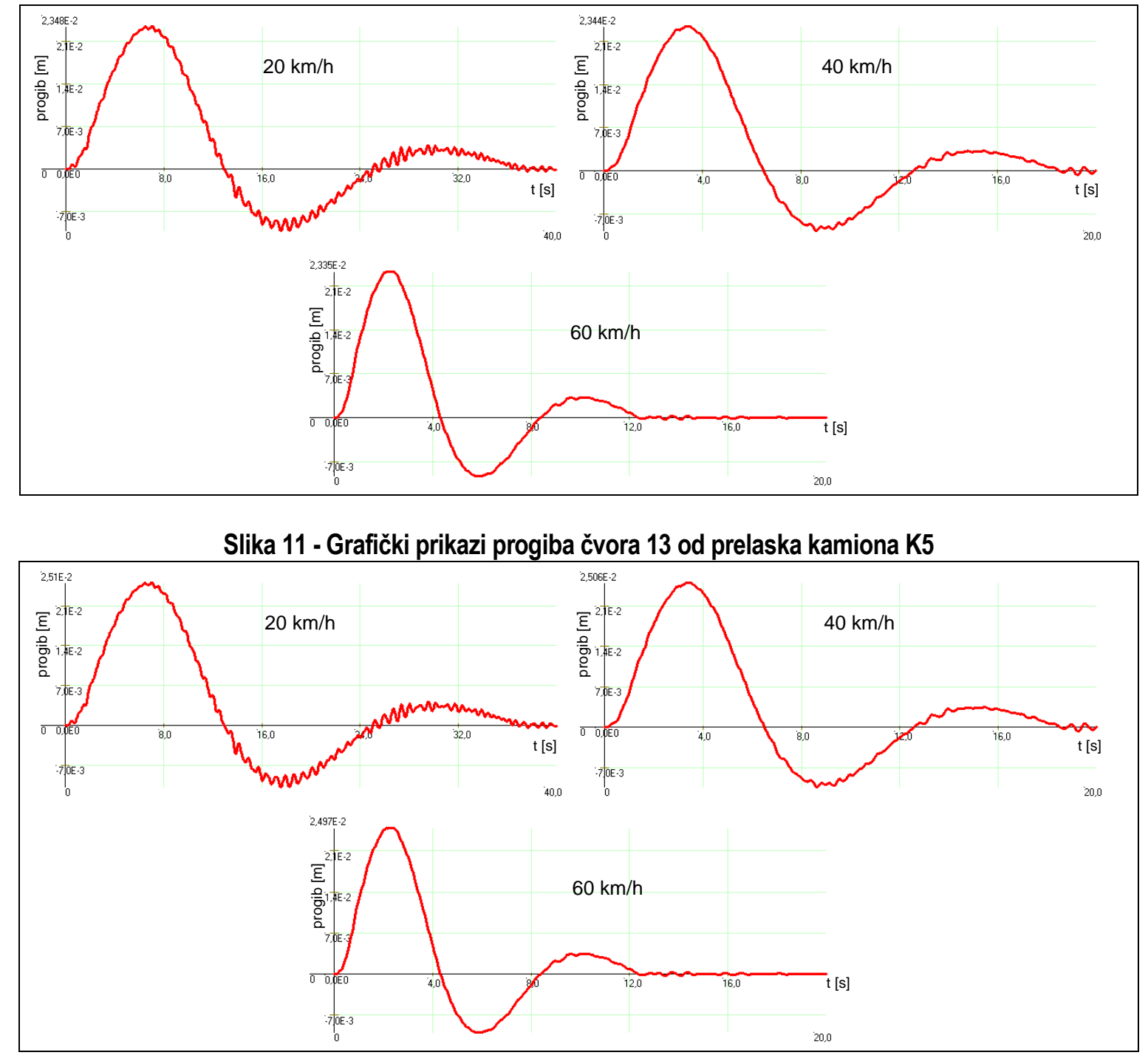

Slika 12 - Grafički prikazi progiba čvora 13 od prelaska kamiona K6

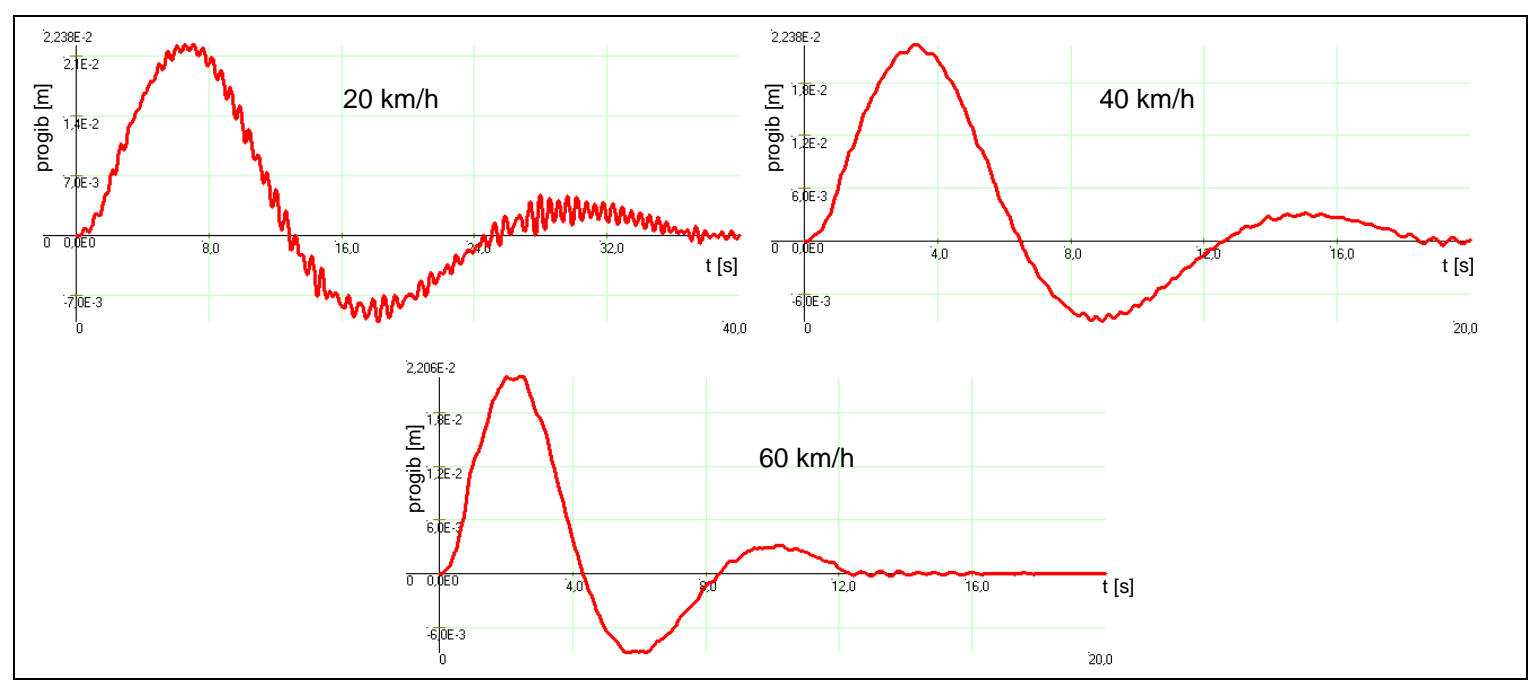

Slika 13 - Grafički prikazi progiba čvora 13 od prelaska kamiona K7 


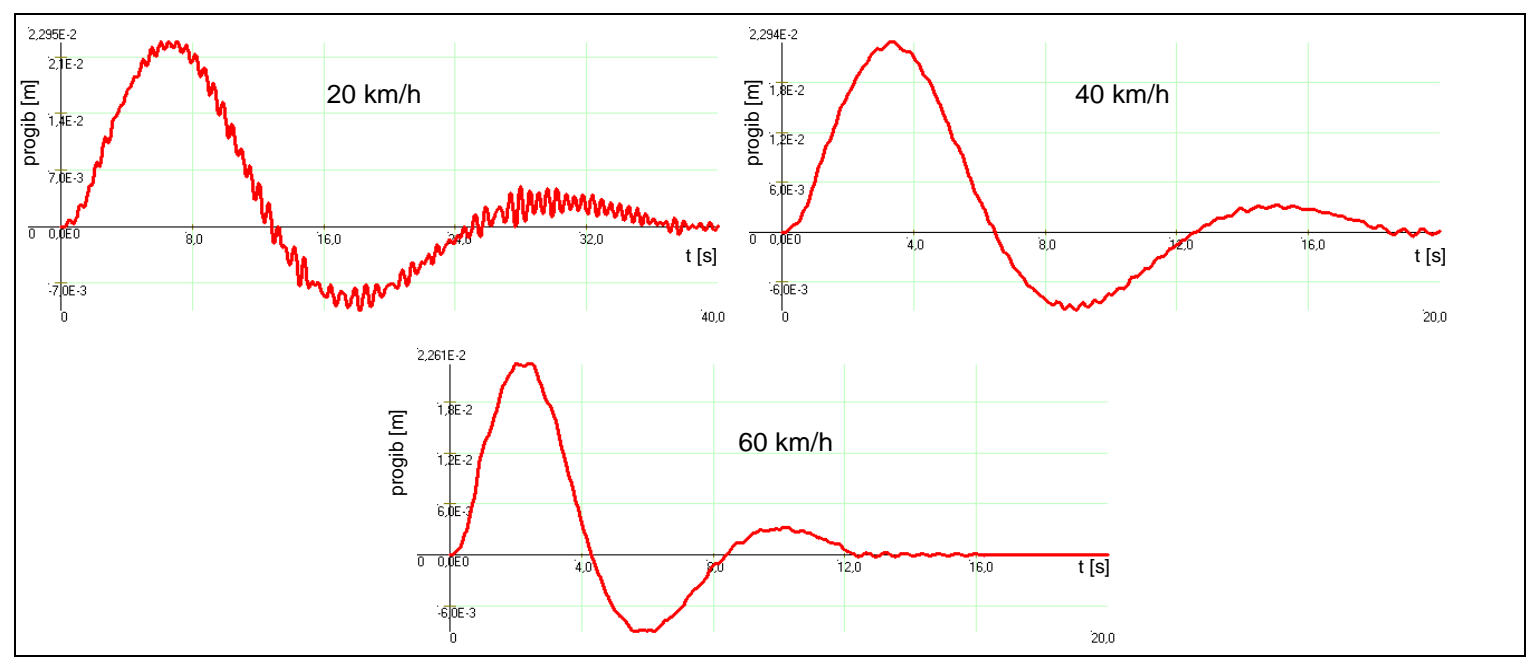

Slika 14 - Grafički prikazi progiba čvora 13 od prelaska kamiona K8

U tablici 3 prikazani su najveći izračunani dinamički progibi u sredini prvog raspona (čvor 13), nastali kao posljedica prelaska pokretnih sila koje simuliranju različite kamione brzinama $20 \mathrm{~km} / \mathrm{h}, 40 \mathrm{~km} / \mathrm{h}$ i $60 \mathrm{~km} / \mathrm{h}$ modelom konstrukcije.

Tablica 3 - Najveći dinamički progib u sredini prvog raspona [cm]

\begin{tabular}{|c|c|c|c|}
\hline \multirow{2}{*}{ Kamion } & \multicolumn{3}{|c|}{ Brzina vožnje } \\
\cline { 2 - 4 } & $20[\mathrm{~km} / \mathrm{h}]$ & $40[\mathrm{~km} / \mathrm{h}]$ & $60[\mathrm{~km} / \mathrm{h}]$ \\
\hline K1 & 1,502 & 1,524 & 1,523 \\
\hline K2 & 1,495 & 1,516 & 1,516 \\
\hline K3 & 1,534 & 1,555 & 1,555 \\
\hline K4 & 1,521 & 1,542 & 1,542 \\
\hline K5 & 2,348 & 2,344 & 2,335 \\
\hline K6 & 2,51 & 2,506 & 2,497 \\
\hline K7 & 2,238 & 2,238 & 2,206 \\
\hline K8 & 2,295 & 2,294 & 2,261 \\
\hline
\end{tabular}

\subsection{Statički proračun konstrukcije}

Statički proračun konstrukcije proveden je u programu DARK kako bi se statički progibi konstrukcije usporedili s dinamičkim progibima. Kamioni su modelirani kao koncentrirane sile (prema tablici 1 i slikama 4 i 5) nanesene na model konstrukcije tako da izazovu najveći progib u sredini prvog raspona (u čvoru 13). Izračunani statički progibi u sredini prvog raspona prikazani su u tablici 4.

Tablica 4 - Statički progibi u sredini prvog raspona [cm]

\begin{tabular}{|c|c|c|c|c|c|c|c|c|}
\hline Kamion & K1 & K2 & K3 & K4 & K5 & K6 & K7 & K8 \\
\hline Progib & 1,485 & 1,477 & 1,516 & 1,503 & 2,325 & 2,486 & 2,204 & 2,26 \\
\hline
\end{tabular}




\section{$5 \quad$ Određivanje dinamičkih koeficijenata}

\subsection{Prema rezultatima provedenih proračuna}

Iz rezultata provedenog statičkog i dinamičkog proračuna izračunan je omjer dinamičkog $\left(f_{\text {din }}\right)$ i statičkog progiba $\left(f_{\text {stat }}\right)$, odnosno dinamički koeficijent $k_{d}$ prema jednadžbi (1)

$$
k_{d}=\frac{f_{\text {din }}}{f_{\text {stat }}}
$$

Izračunani dinamički koeficijenti prikazani su u tablici 5.

Tablica 5 - Izračunani dinamički koeficijenti

\begin{tabular}{|c|c|c|c|}
\hline \multirow{2}{*}{ Kamion } & \multicolumn{3}{|c|}{ Brzina vožnje } \\
\cline { 2 - 4 } & $20[\mathrm{~km} / \mathrm{h}]$ & $40[\mathrm{~km} / \mathrm{h}]$ & $60[\mathrm{~km} / \mathrm{h}]$ \\
\hline K1 & 1,01 & 1,03 & 1,03 \\
\hline K2 & 1,01 & 1,03 & 1,03 \\
\hline K3 & 1,01 & 1,03 & 1,03 \\
\hline K4 & 1,01 & 1,03 & 1,03 \\
\hline K5 & 1,01 & 1,01 & 1,00 \\
\hline K6 & 1,01 & 1,01 & 1,00 \\
\hline K7 & 1,02 & 1,02 & 1,00 \\
\hline K8 & 1,02 & 1,02 & 1,00 \\
\hline
\end{tabular}

\subsection{Prema normama}

Određeni su dinamički koeficijenti prema nacionalnim normama pojedinih zemalja [3] i prema pravilnicima koji su u prijašnjim razdobljima važili u Hrvatskoj [1,2] te su prikazani u tablici 6 . Oznake u tablici 6 su sljedeće: $v$ - brzina kretanja prometnog opterećenja, $P$ - težina prometnog opterećenja, $G=3186 \mathrm{kN}$ - težina konstrukcije u prvom rasponu, $f=1,4 \mathrm{~Hz}$ - vlastita frekvencija konstrukcije, $L=66,28 \mathrm{~m}$ - duljina prvog raspona konstrukcije. U proračun su uzete dvije težine prometnog opterećenja, $P_{1}=280 \mathrm{kN}$ (prosjek težina kamiona K1-K4) i $\mathrm{P}_{2}=435 \mathrm{kN}$ (prosjek težina kamiona K5-K8).

Tablica 6 - Dinamički koeficijenti prema normama

\begin{tabular}{|c|c|c|c|}
\hline Zemlja & Izraz za dinamički koeficijent $k_{d}$ & $\begin{array}{c}\text { Vrijednost dinamičkog } \\
\text { koeficijenta } k_{d}\end{array}$ & Napomena \\
\hline Belgija [3] & $1+0,377 \cdot \frac{v}{L \cdot \sqrt{f}} \cdot \sqrt{1+2 \frac{P}{G}}$ & 1,086 & $\begin{array}{c}v=16,67 \mathrm{~m} / \mathrm{s} \\
P=280 \mathrm{kN}\end{array}$ \\
\hline
\end{tabular}




\begin{tabular}{|c|c|c|c|}
\hline & vrijediza $v \geq 60 \mathrm{~km} / \mathrm{h}$ & 1,09 & $\begin{array}{c}v=16,67 \mathrm{~m} / \mathrm{s} \\
P=435 \mathrm{kN}\end{array}$ \\
\hline \multirow{2}{*}{ Francuska [3] } & $1+\frac{0,4}{1+0,2 \cdot L}+\frac{0,6}{1+4 \frac{G}{P}}$ & 1,033 & $P=280 \mathrm{kN}$ \\
\cline { 2 - 4 } & $1+\frac{(100-L)^{2}}{100 \cdot(250-L)}$ & 1,04 & $P=435 \mathrm{kN}$ \\
\hline Italija [3] & $1+\frac{50}{L+125}$ & 1,06 & - \\
\hline SAD [3] & $1+\frac{20}{L+50}$ & 1,14 & - \\
\hline Japan [3] & vrijedi za čelične mostove & 1,17 & - \\
\hline $\begin{array}{c}\text { Hrvatska [2], } \\
\text { Njemačka [3] }\end{array}$ & $1,4-0,008 L \geq 1$ & 1,00 & - \\
\hline Hrvatska [1] & $1+\frac{550-5 L}{100 \cdot(10+L)}$ & 1,03 & - \\
\hline
\end{tabular}

\section{Zaključak}

U radu su numeričkim proračunom određeni dinamički koeficijenti na mostu Drava u Osijeku zbog prolaska teških kamiona brzinama $20 \mathrm{~km} / \mathrm{h}, 40 \mathrm{~km} / \mathrm{h}$ i $60 \mathrm{~km} / \mathrm{h}$. Dinamički koeficijenti izračunani na temelju proračuna u programu DARK, kojim je rasponska konstrukcija mosta zamijenjena nizom štapnih elemenata u osi sandučastog nosača, variraju od 1,00 do 1,03 .

Dinamički koeficijenti izračunani na temelju izraza definiranih u različitim svjetskim i hrvatskim normama variraju između 1,00 i 1,17. Prema francuskim, njemačkim, te starim hrvatskim normama dinamički koeficijenti se nalaze u rasponu od 1,00 do 1,04 , što se poklapa s vrijednostima proračunanim u ovom radu. Nešto veći koeficijenti su definirani talijanskim $(1,06)$ i belgijskim normama (približno 1,09). Iznimka su vrijednosti dinamičkih koeficijenata određene prema japanskim i američkim normama koje iznose 1,17 i 1,14 i znatnije odstupaju od dinamičkih koeficijenata određenih prema drugim nacionalnih normama.

$\mathrm{U}$ ovome radu uporabljen je programski paket DARK kojim se mogu izračunati dinamički progibi, brzine i ubrzanja bilo koje točke na konstrukciji, koji se pokazao pogodnim za određivanje globalnog dinamičkog koeficijenta zbog dinamičkog pokretnog opterećenja na mostu. Primjer određivanja dinamičkog koeficijenta napravljen je na modelu mosta preko Drave u Osijeku. Prikazani postupak proračuna dinamičkog koeficijenta za konstrukcije koje se mogu modelirati ravninskim štapnim elementima može se rabiti za vrednovanje rezultata dinamičkih ispitivanja konstrukcija i za predviđanje dinamičkog odziva konstrukcija u fazi projektiranja, uz korištenje podataka iz normi i literature.

\section{Literatura}

[1] Furundžić, B.: Privremeni tehnički propisi za opterećenje mostova na putovima PTP-5 (1949), Zbirka tehničkih propisa u građevinarstvu, Građevinska knjiga, Beograd, 1969.

[2] Pravilnik o tehničkim normativima za određivanje veličine opterećenja mostova, Službeni list SFRJ, Beograd, 1991.

[3] Meštrović, D.: Dinamička analiza grednih cestovnih mostova pod prometnim opterećenjem, magistarski rad, Građevinski institut - Fakultet građevinskih znanosti Sveučilišta u Zagrebu, Zagreb, 1986.

[4] EN 1991-2: Eurocode 1: Actions on structures - Part 2: Traffic loads on bridges, CEN, Brussels, 2003.

[5] Konačni izvještaj o pokusnom opterećenju mosta, IGH, Zagreb, 1995.

[6] Kožar, I.: Program DARK, Građevinski fakultet Sveučilišta u Rijeci, 2010. 
[7] http://www.gradri.hr/ modeliranje/Upute_OKVIR.pdf, 25.04.2011.

[8] Štimac, I.: Analiza mostovnih konstrukcija pobuđenih pokretnom masom, magistarski rad, Zagreb, 2003.

[9] Štimac, I.; Meštrović, D.; Kožar, I. 2004: Analiza mostovnih konstrukcija pobuđenih pokretnim opterećenjem, Građevinar, Vol. 56, br. 6, str. 347-353. 